\title{
Design and the global and human wellbeing ${ }^{1}$
}

\author{
Geisy Anny Venâncio ${ }^{\mathrm{a},}$, Adriano Heemann ${ }^{\mathrm{b}}$ and Liliane Iten Chaves ${ }^{\mathrm{c}}$ \\ ${ }^{a}$ Post-Graduate Program in Design, Federal University of Parana, Curitiba, Paraná, Brazil \\ ${ }^{\mathrm{b}}$ Post-Graduate Program in Design, Federal University of Parana, Curitiba, Paraná, Brazil \\ ${ }^{c}$ Technical Drawing Department, Product Design Course, School of Engineering, Fluminense Federal University, \\ Niterói, Rio de Janeiro, Brazil
}

\begin{abstract}
This paper approaches the challenge of considering the principles of sustainable development in the conception of products, services or systems in a specific territory, though inserted in a globalized world. The reflection takes place by crosschecking the information gathered through bibliographical research on the following themes: wellbeing, design, and the local versus global relation. Thus, the strategy of analysis adopted comprehends the triangulation of information for further comparison of the survey and discussion of the data obtained. This paper results in a set of reflections on the interactions between human beings and their territories, towards new conceptions oriented to a more sustainable future.
\end{abstract}

Keywords: Sustainability; ergodesign; satisfaction; need

\section{Introduction}

Sustainable development is related to the fulfillment of the needs of current generations without compromising the future generations' needs, to the detriment of the search for wellbeing in the contemporary world [1]. It is also widely accepted that the idea of sustainability is related to the maintenance of the environmentally correct, socially just, and economically viable.

In that perspective, the field of design takes a fundamental role, since designers create much of the world in which we live, of what is consumed, and of the expectations that are generated [2]. That is, designers shape what is seen, used, and wasted, and, by doing that, have great influence on the way men become involved with the world around them and how they see their future.

Designers have been part of the problem related to the current conditions of the planet [4,2]. However, designers still can and must take a stand as part of the solution, once the issue of improving the quality of the world is an intrinsic part of the concept of design [4]. Designers would be the social actors that deal the most with the day-to-day interactions between human beings and their artifacts. These interactions, added to the related expectations of wellbeing, should change along the transition of humanity towards sustainability [4].

Nonetheless, although the relation between the search for a more sustainable world and what is up for design is understandable, an issue that is still not sufficiently contemplated in studies in the field is evinced: how can designers act in favor of the wellbeing of a global world?

Taking into consideration the broadness of the field of design, this paper aims to introduce specific conceptual explanations about wellbeing. The theme is approached in the ambit of Ergonomics as a discipline that deals with the interactions between men and the elements of their world. The following topics introduce the method employed to carry out this research, the results obtained, and a discussion that stems from crosschecking the collected data.

\footnotetext{
${ }^{1}$ Reflections on interactions between human beings and other elements in favor of a more sustainable future.

*Address for correspondence: Geisy Anny Venancio, Rua Álvaro Bandeira de Melo, 188, Conjunto Jardim Petrópolis, Bairro Petrópolis. CEP: 69067-210. Manaus, Amazonas, Brasil. Tel.: +55 4191223161 or+55 9236118366; E-mail: venancio.anny@gmail.com
} 


\section{Method}

The bibliographical research carried out deals with sustainability, human wellbeing, territory, globalization, and principles of Ergonomics. As a methodological procedure for the analysis of the compiled bibliography, a strategy of triangulation of the information aiming to verify the different perspectives regarding correlated themes for further comparison and discussion is employed. This sort of comparison is a means to make the knowledge of a certain subject more universal, and triangulation ends up constituting efficient proof of validation, in which multiple points of view are combined and crosschecked [9].

Therefore, triangulation is herein considered a way to lend further validity to or enhance the credibility of the results of an investigation, crosschecking results from different approaches. Triangulation, as a strategy, allows the identification, the exploration, and the understanding of the different dimensions of a study, thus enhancing its discoveries and enriching its interpretations [13]. It is in that sense that sustainability is approached in this article under the perspective of design, specifically in the ambit of Ergonomics. The understanding of wellbeing and, lastly, the apparent conflict existing between thinking globally and acting locally are discussed.

\section{Results}

Aiming to relate correlated themes in a profound but not evident - way, the results of the bibliographical research of this article are presented next. According to the International Ergonomics Association (IEA), "Ergonomics is the scientific discipline concerned with the understanding of interactions among humans and other elements of a system, and the profession that applies theory, principles, data and methods to design in order to optimize human wellbeing and overall system performance" [6]. Therefore, Ergonomics promotes an approach that is holistic and centered in the human being, and considers relevant, above all, physical, cognitive, social, organizational, and environmental factors. It may be treated as a discipline that focuses on the conception of products, services or systems that provide improvement in the relation between men and their surroundings.

Ergonomics is even more linked to Design in the perspective of "Ergodesign" [8], a concept that is related to the employment of the principles or Ergo- nomics to the processes of design. This conceptual integration aims to, overall, reach wellbeing as comfort and satisfaction for human beings [8]. Nevertheless, wellbeing is a particularly subjective and nonunivocal theme. For that reason, the positions taken by some scholars about the subject are presented next for further discussion.

The first meaning of wellbeing may be the subjective notion of feeling well and not only of not feeling bad [7]. Thus, wellbeing also means a condition of fulfillment of needs (whether they are conscious or unconscious, natural or psychosocial) and, specifically in the case of human beings, wellbeing implies in meeting biological needs (physical wellbeing), psychological needs (mental wellbeing), and social needs (social wellbeing) [7].

Since Ancient Greece philosophers such as Aristotle already sought to "decipher the enigma of happy existence", which demonstrates that the attention paid to the theme of wellbeing is not recent [10]. While philosophers debate the essence of the state of happiness, it is up to researchers to construct knowledge and formulate scientific evidence about wellbeing [10]. In the ambit of scientific knowledge, the term "happiness" has been translated as subjective wellbeing [5].

Considering, then, the concept of subjective wellbeing, there are three important aspects to be highlighted in this ambit: subjectivity (wellbeing resides within the individual experience); the understanding of wellbeing is not only the absence of negative factors, but also the presence of positive ones; and the inclusion of a global measure in the context of wellbeing, instead of only a limited measure of an aspect of life [3].

Given the aspects mentioned, a brief explanation of the global judgments of life satisfaction related to local aspects will be provided, focusing on the territorial issue involved in the dialectics of global versus local. The issue of standardization of values, attitudes, products, and lifestyles: globalization, amongst other consequences, imposes cultural standardization, whichputs at stake local identity and local cultural heritage [12].

From the same perspective, globalization and quality of life represent ideological processes and constructs that, directly or indirectly, affect the way of life and the perspectives of wellbeing of current and future generations [14]. The phenomenon of globalization may be analyzed considering its contradictory structure, by identifying its antagonistic elements. That is, "on the one hand, it generates a process of homogeneity, standardizing productive and cultural 
elements; however, on the other hand, a universe of differentiations, tensions, and social conflicts arises" [14].

The global world appears and is sustained by local initiatives, highlighting cultural aspects and seeking identity, which were forgotten with the advent of globalization and with the ideas of homogeneity and standardization of forms and ideas. From that perspective, designers appear as agents that can offer alternative solutions so as to innovate material culture, thus enhancing local culture and harmonizing behavioral culture [11].

\section{Discussion}

Adopting the method of triangulation as a means to identify, explore, and understand the different dimensions of a study, the discussion on the theme of sustainability will be presented next, from the perspective of Ergonomics as a discipline of design, of wellbeing, and of the dialectics of global versus local, aiming to elucidate the role of designers in a specific territory in favor of global wellbeing.

According to the aforementioned, Ergonomics is directly related to human comfort as a search for wellbeing. In that ambit, the concept of Ergodesign appears as an integration of the principles of Ergonomics with the processes of design. Ergodesign is accepted, then, as a conciliation of human attributes and the system of conceptualization and development of design. Thus, for the continuity of this discussion, human wellbeing may be considered the fulfillment of needs, at least from the perspective of the interactions between men and other elements of the system. From that perspective, sustainability is noticed as a fundamental aspect to be considered in the conception of those interactions, since it is directly related to the fulfillment of needs of current and future generations.

That is, the search for wellbeing refers to, in the local context, men as individuals. As for the global sphere, the search is different, for it refers to the collective. Thus, the complex "individual versus collective" and "local versus global" relations are evinced. When it comes to global sustainability, many actions may not make sense in local contexts. Taking into consideration, then, the subjective nature of wellbeing and the plurality of men in their different territorial contexts, the need for finding a balance between local and global views is perceived, in a way that it is possible to think globally (in terms of a ho- listic and systemic view), but act locally (in terms of the peculiarities of territories and their individuals), aiming to reach a more sustainable society (Image 1).

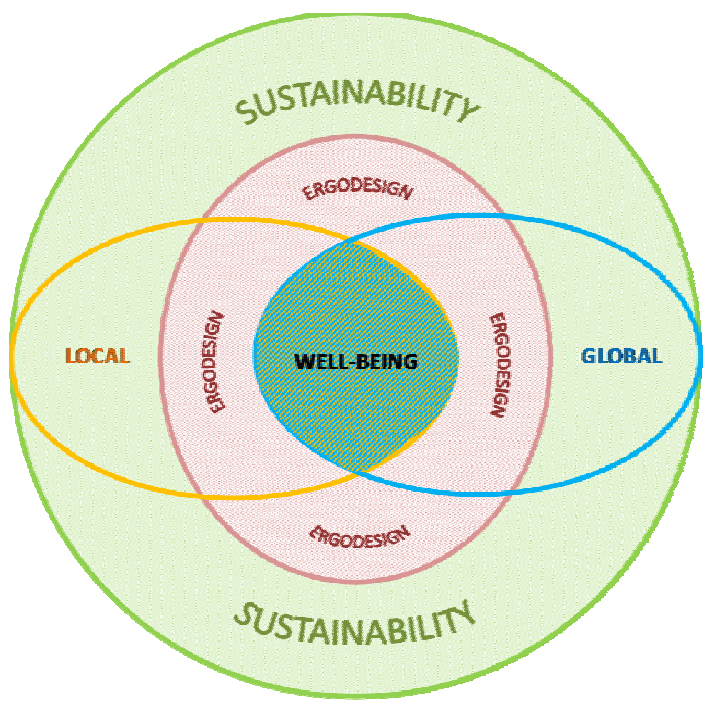

Fig.1 Scheme of relation that involves wellbeing

In the ambit of this discussion, it is possible to conceptualize wellbeing as the core of the topics dealt with herein, sustainability as the wrapper of the issue, and Ergodesign as the concept that underlies all those connections. The orientation is the balance between local versus global relations, since Ergodesign aims to improve the relation between men and their surroundings. Thus, design, in a general ambit, also has the mission to focus on local issues before a global context, so that the wellbeing of current societies does not endanger the wellbeing of future generations.

\section{Concluding Remarks}

The promotion of sustainable solutions requires a systemic view and the integration of competencies of several areas. In times of exacerbated consumerism, looks turn to the field of design, and the discipline of Ergonomics arises as a promoter of new qualitative criteria of wellbeing. In that perspective, the definition of quality of life starts to encompass systems, processes, and relations that are developed in a specific context, but suffer the influence of their surroundings.

In that context, the complex relations revealed by the phenomenon of globalization constantly confront 
men and their several lifestyles. Therefore, the challenge to reach a balance between local identityrelated issues before global surroundings arises, chiefly when it comes to wellbeing. The field of design becomes responsible for the conception of forms of intermediation between men and their surroundings, for the search for a balanced interaction between local and global, and between individual and collective.

Thus, it is up to design to relate, in a favorable way, concepts that apparently are antagonistic. Its role is to reveal local resources and potentialities, so as to provide wellbeing, fulfilling human needs in specific contexts. At the same time, design must promote the integration of diversities through the incorporation of the benefits of global advances.

\section{Acknowledgements}

The authors thank the research support and the financial subsidy granted by Fundação de Amparo à Pesquisa do Estado do Amazonas (Amazon Research Foundation) - FAPEAM, in Brazil.

\section{References}

[1] CMMAD. Nosso Futuro Comum. Comissão Mundial sobre Meio Ambiente e Desenvolvimento. 2. ed. Rio de Janeiro: Editora da Fundação Getúlio Vargas, 1991.

[2] D. Berman. Do good design - How designers can change the world. California: Aiga - New Riders, 2009

[3] E. Diener. Subjective Well-Being. Psychological Bulletin, 95, 542-575. (1984).

[4] E. Manzini. Design para a inovação social e sutentabilidade: comunidades criativas, organizações colaborativas e novas redes projetuais. Rio de Janeiro: E-paper, 2008.

[5] F. Scorsolini-Comin; M. A. Santos. O estudo científico da felicidade e a promoção da saúde: revisão integrativa da literatura. Rev. Latino-Am. Enfermagem [Internet]. mai-jun 2010. Disponível em: http://www.scielo.br/pdf/rlae/v18n3/pt_25.pdf> Acesso em 16 mai 2011.

[6] International Ergonomics Association (IEA) Council. (2000). What is Ergonomics. Disponivel em: < http://www.iea.cc/01 what/What\%20is\%20Ergonomics.html> Acesso em 16 mai 2011 .

[7] L. S. Miranda Sá Jr. Desconstruindo a definição de saúde. Jornal do Conselho Federal de Medicina (CFM), jul/ago/set de 2004. Disponível em: <http://www.unifesp.br/dis/pg/DefSaude.pdf $>$. Acesso em: 16 mai 2011.

[8] L. Yap; T. Vitalis; S. Legg. Ergodesign: from description to transformation. In: 13th Triennial Congress of the International Ergonomics Association. From Experience to Innovation. Helsinki: Finnish Institute of Occupational Health, 1997.

[9] M. C. S. Minayo et al. Pesquisa social: teoria, método e criatividade. Petrópolis: Vozes, 1994.

[10] M. M. M. Siqueira; V. A. R. Padovam. Bases teóricas de bemestar subjetivo, bem-estar psicológico e bem-estar no trabalho. Psic.: Teor. e Pesq., Brasília, v. 24, n. 2, Junho, 2008. Disponível em: http://www.scielo.br/pdf/ptp/v26n3/a18v26n3.pdf $>$ Acesso em 16 mai 2011.

[11]N. S. M. Martins. Design fuzzy em mundos possíveis e de incerteza. In: Anais do $6^{\circ}$ Congresso Brasileiro de Pesquisa e Desenvolvimento em Design - $6^{\circ} \mathrm{P} \& D$ Design. São Paulo, 2004.

[12]R. Ramalho Filho. Globalização, Sustentabilidade e Patrimônio:reflexos sobre a cidade periférica. In: Anais do I Encontro da Associação Nacional de Pós-Graduação e Pesquisa em Ambiente e Sociedade - ANPPAS. Indaiatuba, 2002.

[13]R. Yin. Case Study Research: Design and Methods. Applied Social Research Methods Series, Vol. 5, Sage, USA, 1994.

[14]T. Santos. Globalização e exclusão: a dialética da mundialização do capital. Sociologias, Porto Alegre, n.6, judez.2001. Disponível em: < http://www.scielo.br/pdf/soc/n6/a08n6.pdf> Acesso em: 16 mai 2011. 